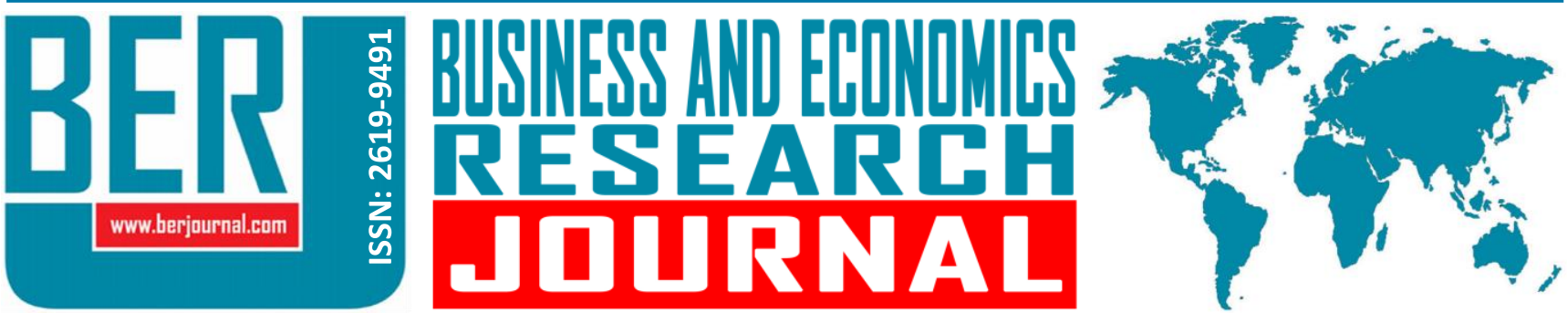 \\ Business and Economics Research Journal Vol. 12, No.1, $2021 \quad$ pp. 145-155 \\ doi: 10.20409/berj.2021.315
}

\section{Service Quality in Private Secondary Schools: Extension to EduQUAL with a case from Turkey}

\author{
Cagri Bulut ${ }^{\mathrm{a}}$, Sefer Aydogan ${ }^{\mathrm{b}}$
}

Abstract: Previous research on measuring the service quality presents alternative assessment instruments of SERVQUAL by customizing the generic indicators of service quality to sector-specific features for various service markets. EduQUAL is the specific method of SERVQUAL assessment for measuring the service quality of educational services. This study contributes to the EdUQUAL literature by extending with a new dimension covering the quality assessment of the core educational services with empirical evidence generated in 2019 over the secondary-school students of private schools operating in Turkey. Therefore, the current study aims to extend the EduQUAL assessment of the private chain schools and aims to which of these successful schools' service quality indicators predict student satisfaction and student loyalty. The study's data represents 305 students' perceptions of a private school operating in Turkey with more than 100 branches. The factor analysis results yield a new dimension related to core educational services. The regression analyses' results reveal that the core educational services predict only student satisfaction with other service quality indicators. Empathy-related services at schools are the most significant indicators of the EduQUAL both on student satisfaction and student loyalty.
Keywords: SERVPERF, Student Attitudes, Private Education, Private Chain Schools, Turkey

JEL: M31, 120

\section{Introduction}

World Bank attributes the private schools as a social business model that aims to deliver value and provide up-to-date education facility, information, and communication technologies (ICT) based modern systems to the children of low-income families for the inclusive development (Tinsley \& Agapitova, 2018). Either their family is poor or not, all children have right to have a good quality of education even if it is a costly opportunity. On the other hand, private schools are searching for leveraging their economies of scale by improving their quality of services (Senol \& Dagli, 2017; Molnar, 2018). However, the parents' investment tendencies on better education options in a national context transform the national education system to a distinct business opportunity, the private school industry. Due to that reason, apart from the private school model of the World Bank, entrepreneurs in developing economies like Turkey find out private schools as a new business model, similar to franchising systems.

More than 20 thousand private schools in Turkey serve a total of 3.4 million students, and half of them serve for primary and secondary education, with 178 thousand teachers (Ozturk, 2018). The average

a Prof., PhD., Yasar University, Faculty of Business, Department of Business, Izmir, Turkiye, cagri.bulut@yasar.edu.tr (ORCID ID: 0000-0002-3291-673X)

b Asst. Prof., PhD., National Defence University, Dean of Air Force Academy, Department of Humanity and Social Sciences, Istanbul, Turkiye, saydogan@hho.edu.tr (ORCID ID: 0000-0002-0431-4256) 
annual private school fees in Turkey are 2,500-USD. The annual fees of private schools with influential brands are up to 20,000-USD, the volume of the private school market except higher education institutions is approximately around 3 billion USD (Ozturk, 2018). Though the number of private schools in Turkey is gigantic, investors keep investing like a franchisee for the new branches of private schools. In addition to the parents' wills on their children for better education, business people transform the education system into a competitive service business. Because school managers become financially limited with the parents' tuition fees, they struggle to improve the service quality, which will result in achieving a sustainable competitive position. Therefore, this study aims to shed some light on school managers' decision problems on which of the quality indicators for private schools are essential for their students?

In Turkey, most private school incomes are based on tuition fees, mostly from middle and highincome families. Compared with Turkey's GDP, the tuition fees of private schools are relatively higher than the "Low-Cost Private Schooling Model" of the World Bank. The private schools' tuition fees vary due to either the competitive conditions at their locations or the differentiation strategies of managers. In line with the "Reaching the Last Mile (2018)" report of the World Bank, the private school managers strive to formulate and implement strategies to differentiate their corporate brands by providing extra or better services to stay competitive in the education market. Thus, the quality of education seems to depend on the enrichment of these schools' differentiated services. On the other hand, private schools search for excellence and quality improvement in addition to the non-educational services to the students and their parents and their core education services.

Despite these facts, the number of private schools is still an increase. It is not surprising that, rather than having a single campus, many private schools with strong brands establish new branches or campuses throughout the country. In this study, we refer to them as Private Chain Schools (PCS). PCS refers to private schools with more than one campus or branches in a country similar to a franchising system. While different individual investors own most of their branches, the brand's founders mostly administer a few PCS. In this sense, especially managing non-educational services quality of PCS becomes essential for managers willing to secure their corporate brands, enlarge their revenues, or penetrate new locations.

According to the best of our knowledge, the literature lacks evidence on measuring the PCS service quality. Moreover, it provides mostly evidence from the higher education level (e.g. Annamdevula \& Bellamkonda, 2016; Latif et al., 2019). The evidence of EduQUAL, as an assessment instrument of educational services, within a secondary school context, remains somewhat limited (i.e. Ramseook-Munhurrun \& Nundlall, 2013; Senol \& Dagli, 2016). Though the studies with EduQUAL present validations of multidimensional theoretical structures, we questioned if the multidimensional theoretical structure of EduQUAL needs customization for private education. Therewithal, we aim to advance the study by examining the influences of the EduQUAL dimensions on their students' attitudes at private secondary schools.

\section{Student Satisfaction and Student Loyalty}

The tuition fees parents pay to private schools promote the values of the differentiated services offered. The excellence in services is the key to the competitive advantage because the service quality predicts repurchasing the same services and recommending them (Berry et al., 1994). Hence, understanding the predictors of student satisfaction and student loyalty is essential for school managers (Najib et al., 2011; Annamdevula \& Bellamkonda, 2016). Moreover, PCS managers consider students as customers (Elliot \& Healy, 2001).

Student loyalty and student satisfaction are processes in which the learning environment is accompanied by academic success (Lo, 2010) and facilities. Significantly, the private schools' physical facilities influence generating student satisfaction (Mansori et al., 2014). To Sultana \& Momen (2017); the factors affecting student loyalty and student satisfaction are "academic issues, economic consideration, infrastructure and image, and prestige". The equipment, the visual aids, the teaching methods, and the modern infrastructure regarding service quality are substantial components for student loyalty and student satisfaction (Shekarchizadeh et al., 2011). For instance, if a teaching process within the academic issues does 
not meet students' expectations, it has difficulties generating student satisfaction. That also reduces the level of student loyalty (Harsasi \& Sutawijaya, 2018).

Since loyalty means a degree of commitment during a period (Oliver, 1999), students' loyalty refers to the intention of belonging and recommendation. Because such students increase the quality of teaching with active participation and recommendations (Helgesen \& Nesset, 2007), students' loyalty can appear in several activities, especially after graduation loyalty becomes obvious. Such as; alumni association, annual meetings, and financial supports. These activities appear to be related to the school's perceived prestige (Osayawe Ehigie \& Taylor, 2009). Researches reveal that loyalty and satisfaction have strong associations (Yu \& Dean, 2001; Hennig-Thurau et al., 2001; Ali et al., 2016). In this study, the student satisfaction construct includes "the student's perception towards administrators' experience, quality of education, teacher quality, foreign language education, physical facilities, empathy." As for student loyalty construct includes items; If I have the chance to choose by my own decision, I would choose my own school again, I feel I belong to my school, in the future I would like to enroll my child to my school in the future, I am delighted I belong to this school, I would also recommend my school to my peers, I would recommend my school to adults who ask me if I am happy at my school.

\section{Service Quality Assessment and Private Secondary Schools}

There is a wide range of service quality assessment methods in literature; SERVQUAL of Parasuraman et al. (1985) and SERVPERF of Cronin \& Taylor (1994) are ahead of the others. The SERVQUAL (Parasuraman et al., 1991) has a generic and multidimensionality theoretical construct for many service settings. Its dimensions range from five to eight. Nevertheless, because the meaning of service is diversified to service type, the measurement seems to be more critical for service quality. The relevant research indicates that the SERVQUAL dimensions have difficulty covering all services provided (Mahapatra \& Khan 2007; RamseookMunhurrun et al., 2013; Senol \& Dagli, 2016; Latif et al., 2019) that results in insufficiency for measuring (Carman, 1990). Despite the concerns about SERVQUAL, the highlights in the literature exhibit that SERVQUAL is adaptable to measure a relevant service quality (Carman, 1990; Cronin \& Taylor, 1992; Ladhari, 2008; Bazzera \& Gomes, 2016; Sari et al., 2016; Latif et al., 2019). For instance, the EduQUAL for service quality at education (Mahapatra \& Khan 2007), the AIRQUAL for airport service quality (Bazzera \& Gomes, 2016), the MSQD for the service quality at yacht-marinas (Sari et al. 2016), the HEALTHQUAL for the healthcare services (Lee, 2017) or the MEQUAL for the service quality of management education (Verma \& Prasad, 2017).

Since service quality in education catches researcher's eye (Shank et al., 1996; Owlia \& Aspinwall, 1996; Joseph \& Joseph, 1997, Chong \& Ahmed, 2012), a limited number of studies (Mahapatra \& Khan 2007, Ramseook-Munhurrun et al., 2013; Senol \& Dagli, 2016; Latif et al., 2019) present evidence from secondary education services, mostly from the university (e.g., Annamdevula \& Bellamkonda, 2016; Latif et al., 2019). EduQUAL, as the theoretically validated assessment instrument of educational services, supports decisionmakers' quality improvement strategies by providing fact-based inputs to improve the quality of both the educational services and on-campus services regarding the non-educational operations (Menon, 2015; Marimon et al., 2019). Mahapatra \& Khan (2007) introduced EduQUAL with five dimensions (learning outcomes, responsiveness, physical facilities, personality development, and academics) to measure educational quality by adapting SERVQUAL. Ramseook-Munhurrun et al. (2013) studied educators' perceptions of service quality of state-schools with SERVQUAL. They produce five dimensions (school facilities, reliability, responsiveness, empathy, and assurance-discipline). Latif et al. (2019) reveal six dimensions with HiEduQual (teacher quality, administrative services, knowledge services, activities, continuous improvement, and leadership quality), Senol \& Dagli (2016) present seven dimensions from the perceptions of students (teaching staff, school activities, testing and evaluation, school achievement, school administration, school physical environment, school guidance, and counseling). Though the studies with EduQUAL present validations of multidimensional theoretical structures, we question if it needs customization for private education. Therewithal, we aim to advance the study by examining the influences of the EduQUAL dimensions on students' attitudes at private secondary schools. 
As with the problems on the refinement and reassessment of SERVQUAL, and despite its multidimensional theoretical structure, the number and names of dimensions vary in each of the EduQUAL research. Surprisingly, a dimension regarding and considering core educational services are missing in previous studies. Then, core educational services are supposed to be associated with fundamental issues of being a school like; education given by the school is updated, course content meets my learning need, what we learned to prepare us for future exams and exams are the subjects that are taught in lessons. Due to the measures of service quality expected to be service-specific and the enormous volume of the sector, we aim to adapt EduQUAL to cover the specific services PCS provides. Besides, the literature as yet has not examined measuring the service quality blended with PCS context. Accordingly, the private secondary schools and the tuition-free state schools may excel their service quality with a more specific and advanced version of the EduQUAL to continuously improve the quality of education and attract more students with high qualifications. Therefore, based on our systematic literature review, while we borrow the method of the EduQUAL and adapt it to the PCS context, we try to cover the missing aspects regarding services related to education. Secondly, we incorporated new aspects into the measures not just from the EduQUAL, but also from the SERVQUAL. Finally, we end the systematic literature review of our study to answer the two questions as below:

1) Does the EduQUAL of PCS have a multidimensional structure, including core educational services?

2) Do the EduQUAL dimensions of PCS services affect student loyalty and student satisfaction?

\section{Method}

\subsection{Research Design and Purpose}

The purpose of the current study is to extend the EduQUAL assessment of the private chain schools and figure out which of these successful schools' service quality indicators predict student satisfaction and student loyalty. Therefore, to cover the educational services in PCS, we first examined the documents like organization standards of private schools, directives of a secondary school within a national education system that shape private school services in 2018. Secondly, we have made observations that allow us to produce additional items related to services by revealing significant differences in the PCS environment. Finally, we reached 72 items by reviewing the measures and/or items that can be included in the questionnaire, not just with side-visits but also with a systematic literature review to measure service quality in the year 2019 . The study scales are all in the 5 graded Likert-type, where 1 indicates strongly disagree, and 5 strongly agree.

\subsection{Data Analysis}

To reduce a large number of education quality variables into a smaller set of education quality variables and also in order to establish the underlying dimensions between existing EduQUAL construct and latent service dimensions (Tabachnick \& Fidell, 2007), we run the factor analysis. Besides, for predicting respectively the student satisfaction and student loyalty based on EduQUAL dimensions associated with respectively the student satisfaction and student loyalty (Büyüköztürk, 2007), we run the multiple regression analysis.

\subsection{Research Sample}

Among more than 10 thousand private secondary schools in Turkey (Ministry of Education, 2019), we aimed to acquire a convenient sample from students over three private secondary schools of a PCS in 2019. The facts that the school's senior management is open to the research on the quality issues and wants to take the research results as an input for improving their educational services were the reasons. The convenience sampling method relies on the data collection process from the related population members who are conveniently available. Business studies can be applied to gain initial primary data related to prospective customers' opinions with a new design of a product (Saunders, Lewis, \& Thornhill, 2012). Thanks to the chain private schools' administration, they surveyed 309 students to reach half of their three schools' population within their PCS. Finally, 305 questionnaires were complete. Accordingly, $98 \%$ of valid 
questionnaires represent about half of these three schools' population in a PCS. The demographics based on frequency distributions and percentages are in Table 1.

Table 1. Demographics of the Participants

\begin{tabular}{llcc}
\hline \multirow{2}{*}{ Gender } & & $\%$ & $\mathrm{~N}(305)$ \\
& Man & 44 & 138 \\
& Woman & 55 & 167 \\
\multirow{2}{*}{ Age } & $14-16$ & 21 & 69 \\
& 13 & 34 & 103 \\
& $11-12$ & 44 & 133 \\
\multirow{3}{*}{ Class } & Class of 6 & 48 & 146 \\
& Class of 7 & 33 & 102 \\
& Class of 8 & 18 & 57 \\
\hline
\end{tabular}

\section{Findings and Results}

\subsection{Factor Analysis}

We have applied two separate factor analyses for the educational service quality variables, and the latter is for the dependent variables. To uncover the dimensions of EduQUAL in PCS, we conduct exploratory factor analysis with 71 items. After several attempts with the data reduction procedure of SPSS with the cut point eigenvalue of 1 and Varimax rotation, the data reduction of EduQUAL variables resulted in five dimensions with 21 items. The five-factor solution of EduQUAL with individual items, their resources, factor loadings, and reliability scores are all in Table.2. In the latter factor analysis regarding the independent variables, we submitted the respective data to the Principal Component Analysis (PCA) procedure. The results of PCA with varimax rotation were as expected. The resources of the items of student loyalty and student satisfaction and their respective factor loadings are in Table 3. Unlike the previous research on EduQUAL, the dimension of core educational services emerged as a component of the service quality of education. The items of all the resulted variables, the sources of each item, and each item's respective factor loading score are in Table 2 and Table 3.

Table 2. Factor Analysis of EduQUAL*

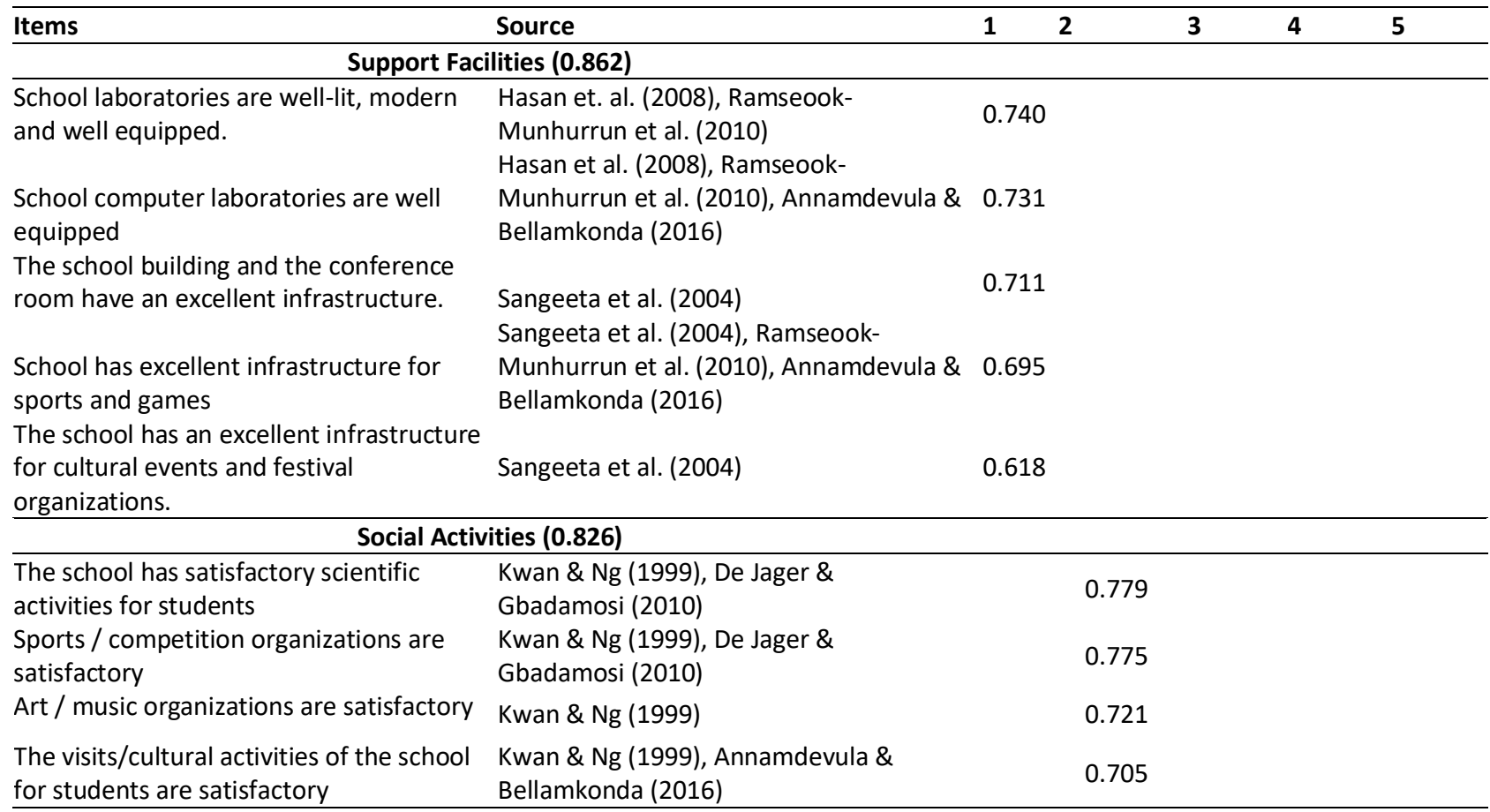


Table 2. Factor Analysis of EduQUAL* (Continued)

What we learned prepares us for future

exams

The education given by the school is

updated

Exams are the subjects that are taught in

lessons

The course content meets our learning

needs.
New item generated

0.753

Hasan et. al. (2008)

0.734

New item generated

0.694

Abdullah (2006)
0.671

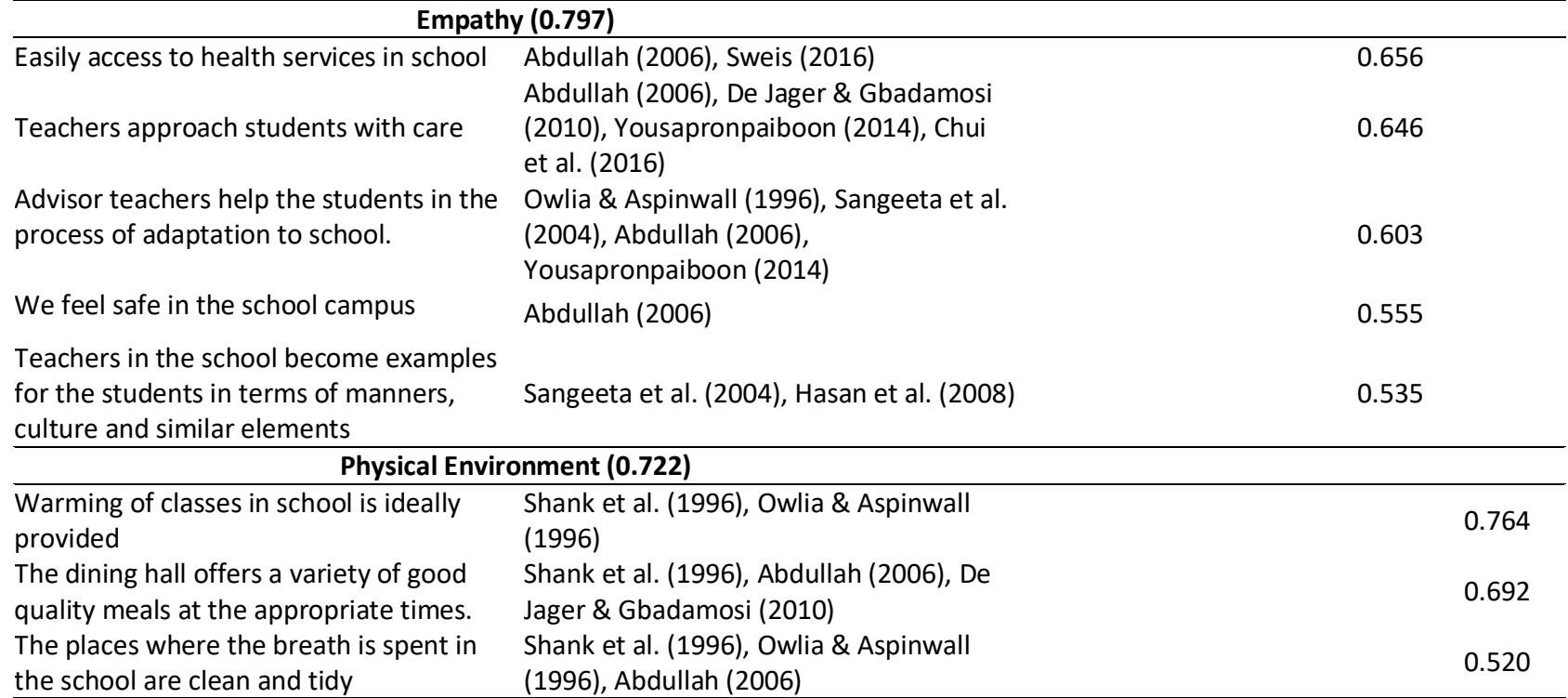

*The Bartlett test of sphericity is significant $\left(x^{2}=2,654.825\right)$. Kaiser-Meyer-Olkin is 0.918 .

The Alpha scores of each dimension are given in parentheses next to the dimension name in Table 2, Table 3, Table 4. The Cronbach's Alpha scores provide that each of the study measures is above the expected 0.70 by showing the reliability of each dimension. For the independent variable service quality, each of the dimensions starting with support facilities contains five items, social activities with four items, core education services with four items, empathy with five items, and physical Environment with three items, total 21 items.

Table 3. Factor Analysis of Dependent Variables

\begin{tabular}{|c|c|c|c|c|}
\hline Items & & Source & 1 & 2 \\
\hline \multicolumn{5}{|c|}{ Student's Loyalty $(0.869)$} \\
\hline \multicolumn{2}{|c|}{ If I have the chance to choose by my own decision, I would again } & Hasan et. al. (2008) & 0.841 & \\
\hline \multirow{2}{*}{\multicolumn{2}{|c|}{$\begin{array}{l}\text { I feel I belong to my school } \\
\text { In the future I would like to enroll my child to my school }\end{array}$}} & New item generated & 0.826 & \\
\hline & & New item generated & 0.822 & \\
\hline \multirow{2}{*}{\multicolumn{2}{|c|}{$\begin{array}{l}\text { I am very happy I belong to this school } \\
\text { I would also recommend my school to my peers }\end{array}$}} & Hasan et. al. (2008) & 0.794 & \\
\hline & & New item generated & 0.744 & \\
\hline \multicolumn{2}{|c|}{$\begin{array}{l}\text { I would recommend my school to adults who ask me if I am happy at } \\
\text { my school }\end{array}$} & New item generated & 0.704 & \\
\hline \multicolumn{2}{|c|}{ Items } & Source & 1 & 2 \\
\hline \multicolumn{5}{|c|}{ Student's Satisfaction (0.933) } \\
\hline Experience of administrators & \multicolumn{3}{|l|}{ Abdullah (2006) } & 0.770 \\
\hline Quality of education & \multicolumn{3}{|c|}{ Hasan et. al. (2008) } & 0.732 \\
\hline Teacher quality & \multicolumn{3}{|c|}{ Annamdevula \& Bellamkonda (2016), Latif et al. (2019) } & 0.721 \\
\hline Foreign language education & \multicolumn{3}{|c|}{ New item generated } & 0.710 \\
\hline Physical facilities of the school & \multicolumn{3}{|c|}{$\begin{array}{l}\text { Sangeeta et al. (2004), Abdullah (2006), Hasan et. al. } \\
\text { (2008) }\end{array}$} & 0.705 \\
\hline Empathy & \multicolumn{3}{|c|}{ New item generated } & 0.678 \\
\hline
\end{tabular}




\subsection{Descriptive Statistics and Correlations}

We also calculated means, standard deviations, in addition to the Cronbach Alpha scores. The correlation scores between each of the EduQUAL dimensions are all significant as in Table 4. The one-to-one correlation of each of the EduQUAL dimensions with student loyalty and student satisfaction is ceteris paribus significant.

Table 4. Descriptive Statistics and Correlation Matrix

\begin{tabular}{lclllllllll}
\hline \multicolumn{1}{c}{ Variables } & Mean & S.D. & Alpha & $\mathbf{1}$ & $\mathbf{2}$ & $\mathbf{3}$ & $\mathbf{4}$ & $\mathbf{5}$ & $\mathbf{6}$ & $\mathbf{7}$ \\
\hline 1-Satisfaction & 3.88 & 1.03 & 0.933 & 1 & & & & & & \\
2-Loyalty & 3.32 & 1.30 & 0.869 & 0.719 & 1 & & & & & \\
3-Empathy & 3.90 & 1.01 & 0.797 & 0.757 & 0.604 & 1 & & & & \\
4-Social Activities & 3.27 & 1.28 & 0.826 & 0.569 & 0.508 & 0.519 & 1 & & & \\
5-Support facilities & 3.35 & 1.20 & 0.862 & 0.687 & 0.585 & 0.605 & 0.650 & 1 & & \\
6-Physical Environment & 3.12 & 1.22 & 0.722 & 0.595 & 0.489 & 0.610 & 0.500 & 0.585 & 1 & \\
7-Core Education & 4.38 & 0.79 & 0.781 & 0.591 & 0.451 & 0.615 & 0.405 & 0.452 & 0.491 & 1 \\
\hline
\end{tabular}

All correlations are significant 0.01 level.

\subsection{Multiple Regression Analysis}

After the data reduction procedure with the SPSS 22 statistical program, to investigate the effects of service quality dimensions on student satisfaction and student loyalty, we applied two separate multiple regression analysis to answer the second question.

After the data was transferred to the statistical package program, the normality assumption, which was considered a prerequisite for passing the multiple regression analysis, was examined. In this context, the preliminary preparation of the data has been made. The values in the \pm 1 interval concluded that the data were suitable for normal distribution. The scatter diagram matrix was examined for the multivariate normality assumption. Since the analyzed distributions were obtained in ellipses, it was concluded that the multivariate normality assumption was also met. When we look at the correlation values between independent variables (See Table 4), there is no multiple correlation problem. Nevertheless, whether the independent variables constitute a multiple correlation problem was determined by looking at the tolerance and VIF values as in Table 5.

Table 5. Collinearity Statistics

\begin{tabular}{lcccc}
\hline \multirow{2}{*}{ Variables } & \multicolumn{2}{c}{$\begin{array}{c}\text { Collinearity Statistics } \\
\text { Student Satisfaction }\end{array}$} & \multicolumn{2}{c}{$\begin{array}{c}\text { Collinearity Statistics } \\
\text { Student Loyalty }\end{array}$} \\
\cline { 2 - 5 } & Tolerance & VIF & Tolerance & VIF \\
\hline Empathy & 0.434 & 2.303 & 0.433 & 2.312 \\
Social Activities & 0.540 & 1.851 & 0.541 & 1.848 \\
Support Facilities & 0.453 & 2.208 & 0.452 & 2.214 \\
Physical Environment & 0.523 & 1.913 & 0.521 & 1.919 \\
Core Education & 0.599 & 1.669 & 0.598 & 1.672 \\
\hline
\end{tabular}

In this context, tolerance values were calculated as in Table 5. The fact that these tolerance values are higher than $>0.10$ has shown no multicolliniearity problem. Besides, the variables in terms of calculated VIF values are less than 3 , it is seen that there is no multicollinearity problem (Tabachnick \& Fidell, 2007). Kurtosis and skewness values were examined for the one-way normality assumption.

We regressed the five EduQUAL dimensions on student satisfaction to examine if educational service quality predicts student satisfaction. The multiple regression analysis results reveal that only the three of the EduQUAL dimensions can predict student satisfaction with $\mathrm{R}^{2}=0.667$ in Table 6 . The regression model is significant with the value of $F=124.776$ at $p<0.000$ level, and the results, $t$-values of beta coefficients are significant only at empathy, support facilities, and core education as in Table 6 
Service Quality in Private Secondary Schools: Extension to EduQUAL with a case from Turkey

Table 6. The Effects of EduQUAL Dimensions on Student Satisfaction

\begin{tabular}{lccc}
\hline EduQUAL Dimensions & Beta & t & Sig. \\
\hline Empathy & 0.420 & 8,395 & $0.000^{*}$ \\
Social Activities & 0.082 & 1,820 & 0.070 \\
Support Facilities & 0.282 & 5,764 & $0.000^{*}$ \\
Physical Environment & 0.055 & 1,209 & 0.227 \\
Core Education & 0.147 & 3,447 & $0.001^{*}$ \\
\hline F=124.776** $\quad \mathrm{R}^{2}=0.667$ & & &
\end{tabular}

The multiple regression analysis results to investigate the effects of service quality dimensions on students' loyalty are in Table 7. The regression model is significant with the value $F=51.048(p<0.000)$, and $R^{2}$ is 0.461 . The results reveal that empathy, social activities, and support facilities have siginificant combined effects on student loyalty.

Table 7. The Effects of EduQUAL Dimensions on Student Loyalty

\begin{tabular}{lccc}
\hline EduQUAL Dimensions & Beta & t & Sig. \\
\hline Empathy & 0.326 & 5,045 & $0.000^{*}$ \\
Social Activities & 0.135 & 2,336 & $0.020^{*}$ \\
Support Facilities & 0.246 & 3,890 & $0.000^{*}$ \\
Physical Environment & 0.040 & 0.675 & 0.500 \\
Core Education & 0.067 & 1,212 & 0.227 \\
\hline F=51.048 $\quad \mathrm{R}^{2}=0.461$ & & &
\end{tabular}

\subsection{Results}

The exploratory factor analysis yielded five dimensions. The solutions of the factor analysis reveal the multidimensionality of service quality indicators in the PCS context. On the other hand, the statistical findings show that "core educational services" are one of the integral dimensions of educational services different from the previous research about EduQUAL. We have reached a five-dimensional solution with 21 items, including the core educational services. The findings answer the first question of this study in the context of the research sample.

Before answering the second question, we aimed to uncover one to one relations of the research variables. As to the Pearson correlation statistics results, the ceteris paribus relations of each EduQUAL dimensions with both the student satisfaction and the student loyalty are all significant. However, while the effects of all EduQUAL dimensions on student satisfaction present that the core educational services and empathy and support facilities have statistically significant and joint effects on student satisfaction, the other two dimensions' effects remained insignificant. Findings on predicting students' loyalty to their schools differed from their satisfaction over the schools' services because the student loyalty is dependent on only the combined effects of empathy, social activities, and support facilities of EduQUAL. To sum up, multiple regression analysis results put forward solutions to the second question, as it partially predicts with only three of the five EduQUAL dimensions.

\section{Conclusion}

Considering that PCS is in the increase for better education, there arouses a need to measure noneducational and core educational services and their effects on student satisfaction and student loyalty. We achieved our aim by obtaining tailored measures of specific services within a PCS. Accordingly, the current study's main contribution after the exploratory factor analysis is to extend a missing quality indicator in the EduQUAL structure. The core educational services surfaced as one of the perceived services and the other specific services in contexts of PCS.

The EduQUAL dimensions that yielded with the study are "empathy", "social activities", "support facilities", "physical environment", and "core education". The empathy dimension refers to how the student's access to health services, how the teachers approach students with care, helps students adapt. It regards 
feeling safe in school, how the teachers become good examples for the students in terms of manners, culture, and similar elements. The dimension of Social Activities is related to social activities organized by the school like scientific activities for students, the school's sightseeing for the students and the cultural activities, sports/competition organizations, arts/music organizations. Support facilities comprise the infrastructures that meet school needs like building and the conference room, sports and games, cultural events and festival organizations, school laboratories, and school computer laboratories. Physical Environment regards the physical assets such as providing the warming of classes ideally, offering a variety of good quality meals at suitable times in the dining hall, and the school's places are clean and tidy. Core Education refers to the perceived quality degree of the educational services, including the quality of the courses and curricula.

Moreover, we examined if the EduQUAL dimensions predict student satisfaction and student loyalty or not. The results reveal that for the PCS managers, to focus on meeting the standards and exceeding them with both educational and non-educational services is vital for the sustainability of their PCS. Due to PCS's tuition fee system, understanding the EduQUAL dimensions is vital for PCS for the enrollment and the for reenroll sustainability.

The assessment of service quality through the students' perceptions has a significant role in quality improvement in PCS. Therefore, the PCS managers may need to consider the study's findings as to make progress on quality not only with core education but also with non-educational services. We do not claim that the findings of the field research are generalizable. However, the findings shed some light not just for administrators of the private schools but also for the state schools, on which of the quality aspects they can attach importance in order to influence student satisfaction and loyalty. Among the other EduQUAL dimensions, the current study reveals that social activities that PCS organize for their students have apparent effects on creating and sustaining student loyalty besides to empathy and support facilities dimensions of EduQUAL.

This study shows that the PCS managers may monitor how the EduQUAL dimensions affect educational services that may positively impact students and indirectly on their parents, including the people at their close affairs. Considering that alumni are one of the important funding sources of well-known educational institutions, the decision-makers of state schools may consider investing in support facilities, enhancing empathy, and organizing social activities to create student loyalty for their schools' wealth in the future. Recalling the UN's Green Mile Report (Tinsley \& Agapitova, 2018), if the school managers may pay specific attention to improve the core educational services and organize social activities, they may likely gather donations from their graduates.

\section{Disclosure Statements}

1. The authors of this article confirm that their work complies with the principles of research and publication ethics.

2. No potential conflict of interest was reported by the authors.

3. This article was screened for potential plagiarism using a plagiarism screening program.

\section{Acknowledgment}

We would like to express our gratitude to the school administrators who supported this study by collecting research data in 2018.

\section{References}

Abdullah, F. (2006). Measuring service quality in higher education: HEdPERF versus SERVPERF. Marketing Intelligence \& Planning, 24(1), 31-47. 
Ali, F., Zhou, Y., Hussain, K., Nair, P. K., \& Ragavan, N. A. (2016). Does higher education service quality effect student satisfaction, image and loyalty? A Study of International Students in Malaysian Public Universities. Quality Assurance in Education, 24(1), 70-94.

Annamdevula, S., \& Bellamkonda, R. S. (2016). Effect of student perceived service quality on student satisfaction, loyalty and motivation in Indian universities: Development of HiEduQual. Journal of Modelling in Management, 11(2), 488-517.

Berry, L. L., Parasuraman, A., \& Zeithaml, V. A. (1994). Improving service quality in America: Lessons learned. Academy of Management Perspectives, 8(2), 32-45.

Bezerra, G. C. L., \& Gomes, C. F. (2016). Measuring airport service quality: A multidimensional approach. Journal of Air Transport Management, 53, 85-93.

Büyüköztürk, Ş. (2007). Data analysis handbook. Ankara: Pegem A Publishing

Carman, J. M. (1990). Consumer perceptions of service quality: An assessment of the SERVQUAL. Journal of Retailing, 66(1), 33-55.

Chong, Y. S., \& Ahmed, P. K. (2012). An empirical investigation of student's motivational impact upon university service quality perception: A self-determination perspective? Quality Higher Education, 18(1), 35-57.

Chui, T. B., Ahmad, M. S. bin, Bassim, F. binti A., \& Zaimi, N. binti A (2016). Evaluation of service quality of private higher education using service improvement matrix. Social and Behavioral Sciences, 224.

Cronin, J. J., \& Taylor, S. A. (1992). Measuring service quality: A Reexamination and extension. Journal of Marketing, 56(3), 55-68.

Cronin Jr, J. J., \& Taylor, S. A. (1994). SERVPERF versus SERVQUAL: Reconciling performance-based and perceptionsminus-expectations measurement of service quality. Journal of marketing, 58(1), 125-131.

De Jager, J., \& Gbadamosi, G. (2010). Specific remedy for specific problem: Measuring service quality in South African higher education. Higher Education, 60(3), 251-267.

Elliot, K. M., \& Healy M. A. (2001). Key factors influencing student satisfaction related to recruitment and retention. Journal of Marketing for Higher Education, 10, 1-11.

Hasan, H. F. A., Ilias, A., Rahman, R. A., \& Razak, M. Z. A. (2008). Service quality and student satisfaction: A case study at private higher education institutions. International Business Research, 1(3), 163-175.

Helgesen, $\varnothing$., \& Nesset, E. (2007). What accounts for students' loyalty? Some field study evidence. International Journal of Educational Management, 21(2), 126-143.

Harsasi, M., \& Sutawijaya, A. (2018). Determinants of student satisfaction in online tutorial: A Study of a distance education institution. Turkish Online Journal of Distance Education, 19(1), 89-99.

Hennig-Thurau, T., Langer, M. F., \& Hansen, U. (2001). Modeling and managing student loyalty: An Approach based on the concept of relationship quality. Journal of Service Research, 3(4), 331-344.

Joseph, M., \& Joseph, B. (1997). Service quality in education: A student perspective. Quality Assurance in Education, 5(1), 15-21.

Kwan, P. Y., \& K. Paul, W. K. Ng, (1999). Quality indicators in higher education-comparing Hong Kong and China's students. Managerial Auditing Journal, 14(1/2), 20-27.

Ladhari, R. (2008). Alternative measures of service quality: a review. Managing Service Quality: An International Journal, 18(1), 65-86.

Latif, K. F., Latif, I., Farooq Sahibzada, U., \& Ullah, M. (2019). In search of quality: measuring higher education service quality (HiEduQual). Total Quality Management \& Business Excellence, 30(7-8), 768-791.

Lee, D. (2017). HEALTHQUAL: A multi-item scale for assessing health-care service quality. Service Business, 11(3), 491516.

Lo, C. C. (2010). How student satisfaction factors affect perceived learning. Journal of the Scholarship of Teaching and Learning, (10)1, 47-54.

Mahapatra, S., \& Khan, M. (2007). A neural network approach for assessing quality in technical education: An empirical study. International Journal of Productivity and Quality Management, 2(3), 287-306.

Mansori, S., Vaz, A. F., \& Ismail, Z. (2014). Service quality, satisfaction and student loyalty in Malaysian private education. Asian Social Science, 10(7), 57-66.

Marimon, F., Mas-Machuca, M., Berbegal-Mirabent, J., \& Llach, J. (2019). UnivQual: A holistic scale to assess student perceptions of service quality at universities. Total Quality Management \& Business Excellence, 30(1-2), $184-200$. 
Menon, S. A. (2015). Enhancing service quality in higher education. Journal of Research \& Method in Education, 5(5), 5560.

Molnar, A. (2018). Giving kids the business: The commercialization of America's schools. New York: Routledge.

Najib, N., Ulyani, M., Yusof, N. A., \& Abidin, N. Z. (2011). Student residential satisfaction in research universities. Journal of Facilities Management, 9(3), 200-212.

Oliver, R. L. (1999). Whence consumer loyalty? Journal of Marketing, 63, 33-44.

Osayawe Ehigie, B., \& Taylor, M. (2009). Managing students' loyalty to school after graduation through relationship marketing. The TQM Journal, 21(5), 502-516.

Owlia, M. S., \& Aspinwall, E. M. (1996). A framework for the dimensions of quality in higher education. Quality Assurance in Education, 4(2), 12-20.

Ozturk, A.B. (2018). The Sector of private education in Turkey (Ozel egitim sektoru). İstanbul: Sector Report in Turkish by the Economics Research Department of Turkiye Is Bankasi. Retrieved from https://ekonomi.isbank.com.tr/ContentManagement/Documents/sr201801_ozelegitimsektoru.pdf (Access Date: 23.04.2019)

Parasuraman, A., Zeithaml, V. A., \& Berry, L. L. (1985). A conceptual model of service quality and its implications for future research. Journal of Marketing, 49(4), 41-50.

Parasuraman, A., Berry, L. L., \& Zeithaml, V. A. (1991). Refinement and reassessment of the SERVQUAL scale. Journal of Retailing, 67(4), 420-450.

Ramseook-Munhurrun, P., Naidoo, P., \& Nundlall, P. (2010). A proposed model for measuring service quality in secondary education. International Journal of Quality and Service Sciences, 2(3), 335-351.

Ramseook-Munhurrun, P., \& Nundlall, P. (2013). Service quality measurement for secondary school setting. Quality Assurance in Education, 21(4), 387-401.

Sangeeta, S., Banwet, D. K., \& Karunes, S. (2004). A SERVQUAL and QFD approach to total quality education: A student perspective. International Journal of Productivity and Performance Management, 53(2), 143-166.

Sari, F., Ozer, Bulut C., \& Pirnar, I. (2016). Adaptation of hospitality service quality scales for marina services. International Journal of Hospitality Management, 54, 95-103.

Saunders, M., Lewis, P., \& Thornhill, A. (2007). Research methods in business studies (4th ed.). Harlow: Prentice-Hall

Senol, H., \& Dagli, G. (2016). Quality improvement in secondary schools: Developing a school self-evaluation scale. Journal International of Educational Sciences, 15(1-2), 53-65.

Senol, H., \& Dagli, G. (2017). Increasing service quality in education: Views of principals and teachers. Eurasia Journal of Mathematics, Science and Technology Education, 13(8), 4857-4871.

Shank, M. D., Walker, M., \& Hayes, T. (1996). Understanding professional service expectations: Do we know what our students expect in a quality education? Journal of Professional Services Marketing, 13(1), 71-89.

Shekarchizadeh, A., Rasli, A., \& Hon-Tat, H. (2011). SERVQUAL in Malaysian universities: Perspectives of international students. Business Process Management Journal, 17(1), 67-81.

Sultana, S., \& Momen, A. (2017). International student satisfaction and loyalty: A comparative study of Malaysian and Australian higher learning institutions. Journal of Intercultural Management, 9(1), 101-142.

Sweis, R., Diab, H., Mahmoud Saleh, F. I., Suifan, T., \& Dahiyat, S. E. (2016). Assessing service quality in secondary schools: The case of Jordan. Benchmarking: An International Journal, 23(5), 1207-1226.

Tabachnick, B. G, \& Fidell, L. S. (2007). Using multivariate statistics. Boston: Pearson Education Inc.

Tinsley, E., \& Agapitova, N. (2018). Reaching the last mile: Social enterprise business models for inclusive development. Washington DC: World Bank.

Verma, S., \& Prasad, R., K. (2017). The MEQUAL scale: Measure of service quality in management education. International Journal of Comparative Education and Development, 19(4), 193-206.

Yousapronpaiboon, K. (2014). SERVQUAL: Measuring higher education service quality in Thailand. Social and Behavioral Sciences, 116, 1088-1095.

Yu, Y. T., \& Dean, A. (2001). The contribution of emotional satisfaction to consumer loyalty. International Journal of Service Industry Management, 12(3), 234-250. 
This Page Intentionally Left Blank 